\title{
Distribution and Economic Potential of Manganese Deposits in Nigeria: A Review
}

\author{
Ojo Adeoye Akintola ${ }^{1^{*}}$ \\ ${ }^{1}$ Department of Geology, Faculty of Physical Sciences, Ahmadu Bello University, Zaria, Nigeria. \\ Author's contribution
}

The sole author designed, analysed, interpreted and prepared the manuscript.

Article Information

DOI: $10.9734 / A J G R / 2019 / v 2 i 130076$

Editor(s):

(1) Dr. Hani Rezgallah Al-Hamed Al-Amoush, Associate Professor, Department of Earth and Environmental, Institute of Earth and Environmental, Al al-Bayt University, Jordan. Reviewers:

(1) Mahamuda Abu, University for Development Studies, Tamale, Ghana. (2) Snehadri B. Ota, Institute of Physics, Bhubaneswar, India. (3) Nguyen Ba Dai, Vietnam Academy of Sciences and Technology (VAST), Vietnam. (4) Mathieu Nanema, Unibersité de Ouagadougou, Burkina Faso. (5) Casimiro S. Munita, Nuclear and Energy Research Institute, Brazil. Complete Peer review History: http://www.sdiarticle3.com/review-history/46745

Review Article

Received 19 November 2018

Accepted 27 January 2019

Published 25 February 2019

\begin{abstract}
The Northern basement complex of Nigeria contains a large number of manganese deposits. So far, ten deposits of manganese have been reported by previous workers. These deposits occur within Precambrian metasediments (schist belt), mafic and ultramafic rocks which are Proterozoic in age and folded into synclinorial belts within the crystalline basement complex. Considering their widespread distribution in space, time and tectonic setting, some are considered to be of ensilalic mode of evolution while others are ensimatic. However, the mineralizations are mostly of poor grade, and thus require beneficiation processing. The local steel industries within the country have continued to depend on manganese ore. No satisfactory substitute for manganese in steel production has been identified as at present. The applications of manganese deposits by geologists, chemical and environmental engineers, ceramicists, soil scientists and microbiologists shows a bright future for manganese ore in Nigeria. The ever increasing demand for steel products has continued to put pressure on Federal Government of Nigeria to complete the construction work at the nation's steel producing plant which, will result in the need for a manganese concentrates for economic growth and development.
\end{abstract}


Keywords: Northern basement complex; schist belt; mineralizations; beneficiation; tectonic setting; concentrates.

\section{INTRODUCTION}

The surface area of Nigeria $923,768 \mathrm{~km}^{2}$ is covered in nearly equal proportions by crystalline and sedimentary rocks [1]. The Nigerian Basement Complex is characterized by different grades of metamorphism, orogenies and structural modifications $[2,3,4]$ and these have been reflected in its complex petrological, structural composition and mineralization potential. The younger metasediments in Nigeria are well known for their mineralization such as Gold, Banded Iron Formation (BIF), lead / zinc ores, tantalite manganese deposits and marble are associated with them [5,6,7]. Nigeria has over $5,000,000$ metric tons (MT) of manganese deposit $[8,9]$.

\section{PREVIOUS WORKS}

The geology of the Nigerian basement complex has received considerable attention from geologists in Nigeria and abroad, partly due to its economic significance and partly because of its unusual geological character. Prior to the minerals ordinances [10] a legal guidelines under which mining companies could operates in a particularly concession was passed in [11,12]. The mining companies had concessionary rights to commence their geological and geophysical investigations in the area allocated under the 1907 ordinance to explore parts of the Nigerian basement complex [12]. Since the pioneering work by several authors $[13,14]$ that conducted the first geological description and introduced basement terrain in literature, several authors have contributed to the geology, structure, geochemistry and geochronology knowledge on granitic and volcanic rocks constituted of these lithology. Previous studies covered the schist belts includes the works of several authors [15-37] while the amongst the (earlier documentation on manganese mineralization appeared in the works of several authors [19,3844]; [38] identified pelitic and semi pelitic rocks, banded iron rocks, amphibolites and other minor rocks, like magnesian rich (talcose rock) and schistose varieties in the basement complex.

Several studies have investigated the geochemistry of rocks identified by [38] in Kushaka belts includes $[18,19,26,25,20]$, though the majority are concerned with the tectonic evolution of the area mainly on granites, amphibolites, gold and talcose rocks. [25,20] considered the Kushaka and Anka areas to be fault-controlled rift-like structures. [28] considered the Anka area to have formed in a separate basin.

Other works done on manganese mineralisations in Nigeria were related to beneficiation of manganese ores [43,44] The investigation carried out by [43] in Madaka focused on appraisal of manganese deposits in the study area with emphasis on its metallurgical features. They produced crystals of manganese II sulphate having $97 \%$ purity after purification process using dilute sulphuric acid as solvent. [44] affirmed the hydrometallurgical extraction of manganese metal by thermal decomposition of the purified manganous nitrate $\left(\mathrm{MnN}_{2} \mathrm{O}_{6}\right)$ crystals to synthesized the chemical manganese dioxide (CMD) from Madaka area. Several authors $[45,46]$ envisaged complex volcano sedimentary trough deposits, with the formation in the belt being lateral facies equivalents. In supporting this view, [47]; [1] proposed the formation of back-arc graben-like structures in Pan-African times to be responsible for the formation of the this belt. The study areas shown numerous features typical of an Archean basement, like grey gneisses and amphibolites displaying greenstone - belts affinities, Archean U-Pb zircon ages and numerous $\mathrm{Nd}$ models ages older than $2.7 \mathrm{Ga}$ $[27,48,49]$. Few studies focused on the Banded iron formations (BIFs) that are found alternating with manganese ores in the study area includes; $[50,51,42,39,52]$. A study by [42] revealed the association between BIFs and manganese in the Maru area. He recognized the presences of sedimentary cycles of BIFs and braunites, lutite in the area. He drew attention to the fact that the vast majority of manganese deposits are of sedimentary character and emphasized on the importance of additional processes like sea- floor volcanic activity, sea level fluctuations, climate changes, biological productivity) as critical in the development of large accumulation of maganiferrous sediments in depositional environment.

Studies by several authors $[39,53]$ were aimed at upgrading of the manganese ore. These authors worked on decolourization of manganese ore from Maikujeri area using magnetic separation and acid bleaching as route for beneficiation. [52] 
assessed the manganese deposits in the area with emphasis on its industrial application.

\section{GEOLOGY OF NIGERIA}

Nigeria is situated within the Pan-African mobile belt, which is a part of an Upper Proterozoic mobile belt, extending from Algeria across the Southern Sahara into Nigeria, Benin and Cameroon. The Pan- African belt continues into north-eastern Brazil, where manganese rocks are also known to occur [38]; [39]. It is situated between the Archean- Paleoproterozoic blocks of West African Craton in the west, the Congo Craton in the south east and the east Sahara block in the northeast [54] (Fig. 1). All models of evolution of the schist belts of Nigeria formulated over the years have been classified under ensialic and ensimatic processes of formation $[55,23,56,22,57]$.

The Northern basement complex of Nigeria contains a large number of manganese deposits. So far, ten deposits of manganese ore have been reported in various parts of the Nigeria where they are associated with the mafic and ultramafic complexes and metasediments of the basement complex $[38,9,39,41,59,60]$.

\section{DISTRIBUTION OF MANGANESE DEPOSITS IN NIGERIA}

The manganese occurrences of north western Nigeria have been variously reported. [61] worked on the manganese deposits at Mallam Ayuba within the Maru schist belt. They observed that the manganese mineralization occurs in ridges for over $800 \mathrm{~m}$ along a north- south strike and lying near Mallam Ayuba settlement. The ore bodies composed of massives brown- grayblack, jointed or fractured, fine-grained iron manganese mineralization dipping at $85^{\circ}$ east with strike direction of $110^{\circ}$ [62]; having a conformable beds of quartzite that contains banded iron formation (BIF), gold and amphibolites [63]. The Tudun Kudu manganiferous ore occur within Precambrian metasediments (Karaukarau schist belt) which are Proterozoic rocks, folded into synclinorial belts within the crystalline basement complex, and metamorphosed to phyllites, quartzites and psammitic schists of low to medium grade $[64,65]$. Available studies show that small quantities of manganese deposits have been reported from basement rocks in South-eastern and South-western parts of Nigeria [66,67] (Fig. 2).

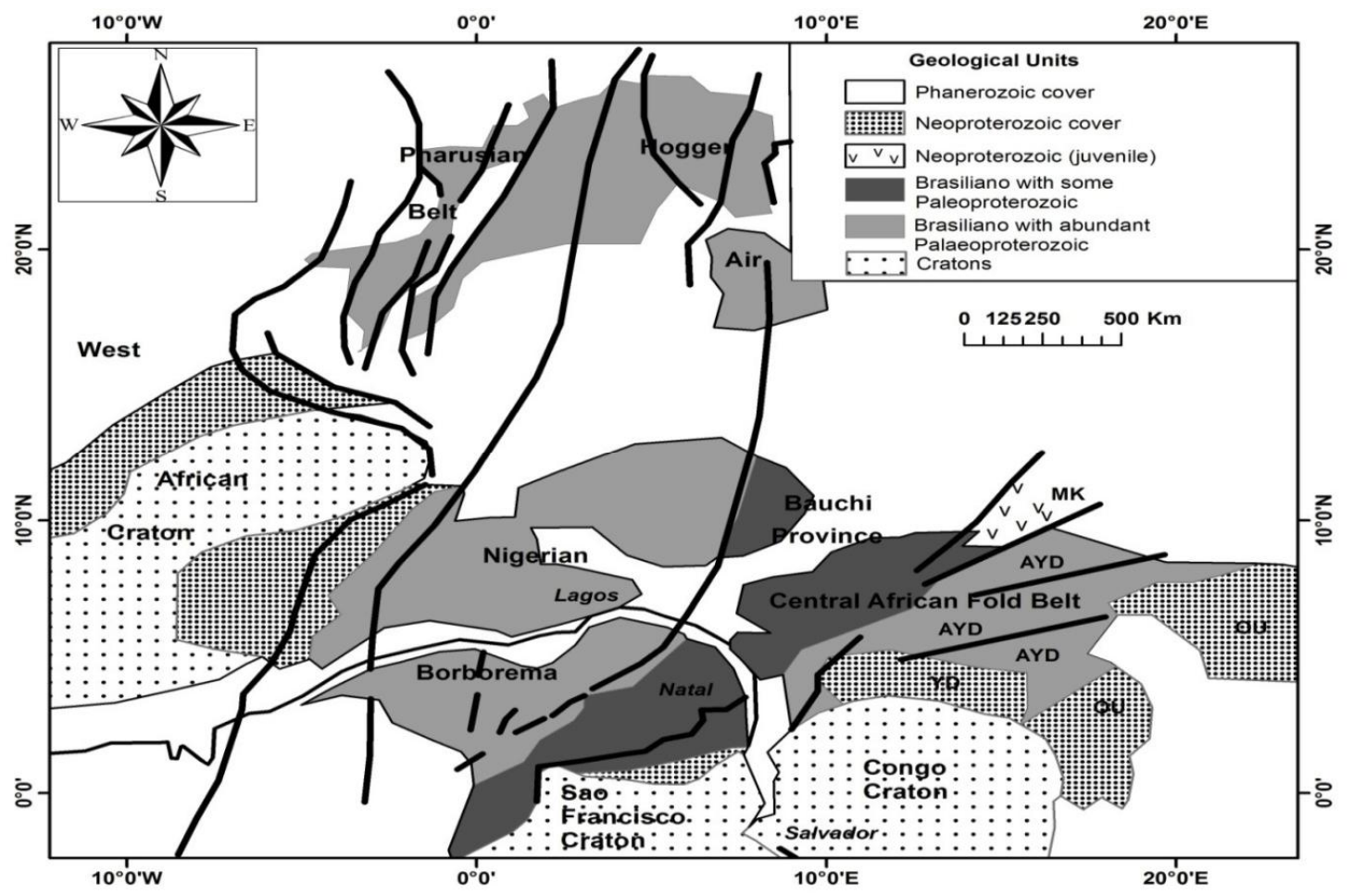

Fig. 1. Pre- drift Proterozoic belts and their Phanerozoic cover rocks between the Cratons [58] 


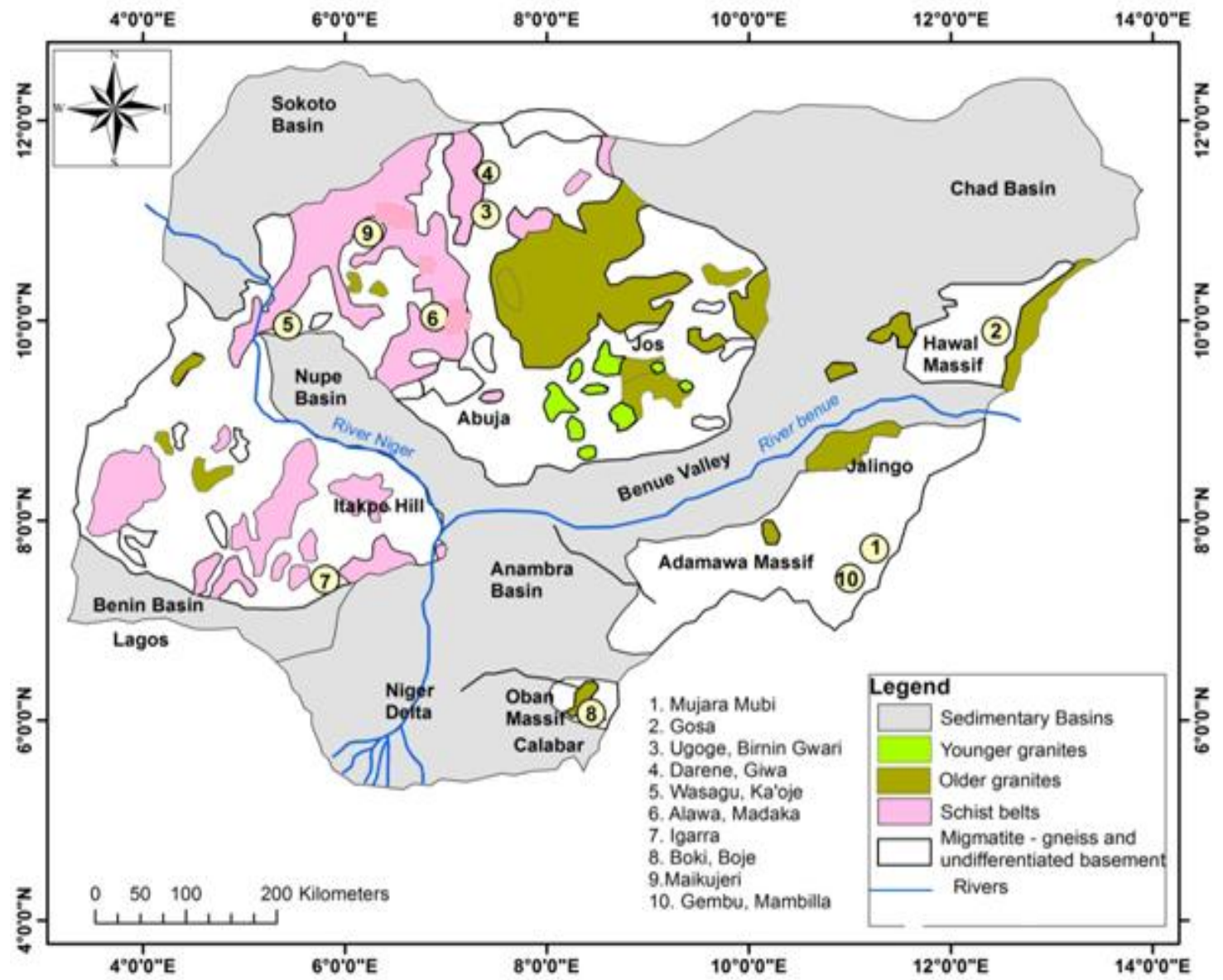

Fig. 2. Simplified geological map of Nigeria Basement Complex showing the occurrence of manganese deposits (Modified after [5,57])

Table 1. Summary of occurrences and distribution of manganese deposits in various locations in Nigeria

\begin{tabular}{llllll}
\hline S & State & Location & Grade & $\begin{array}{l}\text { Estimated } \\
\text { Reserve (Ton) }\end{array}$ & References \\
\hline 1 & Niger & Madaka & - & $\mathrm{Nd}$ & {$[60]$} \\
& & Alawa, & Low & & {$[63]$} \\
2 & Edo & Igarra & - & $\mathrm{Nd}$ & {$[67]$} \\
3 & Adamawa & Mubi & Low & $\mathrm{Nd}$ & {$[68]$} \\
4 & Kebbi & Ka'oje. & Low & $\mathrm{Nd}$ & {$[43]$} \\
& & Wasagu/Danko & - & - & {$[52] ;[53]$} \\
5 & Borno & - & - & - & {$[40]$} \\
7 & Cross River & Duoala & Low & $\mathrm{Nd}$ & {$[66]$} \\
8 & Zamfara & Maikujeri, Darene & Low & - & {$[41]$} \\
9 & Kaduna & Mallam Ayuba, & Low & $\mathrm{Nd}$ & {$[39]$} \\
& & Birnin Gwari & & & {$[59]$} \\
& & & & & {$[40]$} \\
& & & & {$[63] ;[62] ;[56]$} \\
& & Ugoge (S/W) & Low & - & {$[69]$} \\
& & Ugoge (S/E) & Low & - & {$[70]$} \\
\hline
\end{tabular}


However, the mineralizations are mostly of poor grade, and thus require some processing to improve quality for industrial uses. Studies by several authors $[39,53]$ were aimed at upgrading of the manganese ore. These authors worked on decolourization of manganese ore from Maikujeri and Kaoje area using magnetic separation and acid bleaching as route for beneficiation. [52] assessed the manganese concentrates in the area with emphasis on its industrial application. Table 1 gives the summary of the major manganese deposits occurrence in Nigeria.

\section{ECONOMIC POTENTIAL OF MANGANESE IN NIGERIA}

The use of manganese in steel production is a double-edged sword, as the metals fortune is intimately tied to the steel industry. Hence, the need to develop a simple and practicable route for the processing and extraction of manganese from its ores is necessary. The use of Manganese in dyes, paints, battery cells, glass and textiles industries is also of great importance.

In Nigeria, for instance, the per capital consumption of steel is very low. About $10 \mathrm{~kg}$ or less is the index used to determine the level of industrialization of a country. Statistics showed that Nigeria is lagging behind; and other countries with lesser endowments like Zimbabwe $(25 \mathrm{~kg})$, Egypt $(42 \mathrm{~kg})$, Algeria (38 kg) and South Africa $(112 \mathrm{~kg})$, are ahead of Nigeria in terms of steel production and consumption [59].

(1) Steel processing: The various end-uses of manganese have different ore requirements giving rise to the classification of manganese ore into metallurgical, chemical and nonmetallurgical grades. The biggest use of manganese is for the production of steel and cast iron [39,43,60]. Manganese has two important properties in steelmaking: its ability to combine with sulphur to form Alabandite (MnS) and its deoxidation capacity [42].

(2) As alloy: [52] reported that about $94 \%$ of the manganese ore is converted into manganese alloy, These are used in production of stainless steel, heat resistant steel and electric welding electrodes, and as an alloying element in steel where it improves the strength, toughness, hardenability, workability, abrasion resistance of steel and electrical conductors.
(3) Environmental uses: Mn oxides have been used for many different applications in water and waste water treatment as deoxidizer; soil and sediment remediation (of metals and organics); For example, a widely used filtration medium for drinking water is manganese greensand (glauconite with $\mathrm{Mn}$ oxides of various $\mathrm{Mn}$ valence states), designed specifically to remove $\mathrm{Mn}(\mathrm{II}), \mathrm{Fe}(\mathrm{II})$, hydrogen sulfide, and arsenic [51].

(4) It serves as catalysts and adsorbents in the laboratory: The oxidation of $\mathrm{Mn}^{2+}$ to $\mathrm{Mn}^{3+}$ and $\mathrm{Mn}^{4+}$ is largely catalyzed by micro organisms and greatly accelerates the rate of oxidation in many environments. Owing to the high activation energy, the oxidations of $\mathrm{Mn}^{2+}$ act as adsorbents in the laboratory.

\section{CONCLUSION}

Previous workers like $[38,67,9,39,59,43,60]$ revealed that manganese deposit reserves exist in Nigeria, which have potentials as raw materials for industrial applications such as batteries, steel and electrical appliances. The present level of exploitation is, however, very low and in most cases, appropriate processing would be necessary to attain desirable qualities.

\section{ACKNOWLEDGEMENTS}

The writer expresses his appreciation to Professor T. Najime for critical reading of the main work. The author also wishes to thank Professor P.O Ogunleye for much helpful criticism during the course of the work.

\section{COMPETING INTERESTS}

Author has declared that no competing interests exist.

\section{REFERENCES}

1. Rahaman MA. Recent advances in the study of the basement complex of Nigeria. In: Precambrian Geology of Nigeria. Geological Survey of Nigeria. 1988;11-14.

2. Odeyemi IB. Late-Proterozonic metconglomerates in the Schist Belt of Nigeria: Origin and tectonostratigraphic significance revisited. Journal of Technoscience. 1977;3:48-55.

3. Ajibade AC, Woakes M, Rahaman MA. Proterozoic crustal development in the 
Pan-African regime of Nigeria. In: A. Krooner (Editor), Proterozoic crustal evolution. Geodynamic Services American Geophysics Union. 1987;17:259-271.

4. Caby R. Precambrian terranes of BeninNigeria and Northeast Brazil and the Late proterozoic South Atlantic fit. American Spectrum Paper. 1989;230:145-158.

5. Woakes M, Ajibade CA, Rahaman MA. Some metallogenic features of the Nigerian Basement Complex. Journal of Africa Science. 1987;5:655-666.

6. Dada SS, Birck JL, Rahaman MA. Archean Migmatite - Gneiss Complex of Northcentral Nigeria: Its geochemistry and evolution. International Colloquium on African Geology, Mbabane Swaziland. 1989;1:97-102.

7. Oyinloye AO. Geology and geochemistry of some crystalline basement rocks in llesha area Sourthwestern Nigeria: Implications on provenance and evolution. Journal of Science India Research. 2006;50:223-231.

8. MSMD. Ministry of solid minerals and development: An inventory of solid minerals in Nigeria. Geological Survey of Nigeria Press. 1997;59.

9. RMRDC. Non metallic in Nigeria: Raw Material Research and Development Councils, Abuja. 2009;13.

10. Colonial Reports. Report on minerals ordinance and mining resources. National Archives Enugu. 1914;95.

11. Colonial Reports. Minerals ordinance section 2(a-d), WF, National Archives Enugu. 1906;129.

12. Colonial Reports. Minerals ordinance of Nigeria C80, National Archives Ibadan. $1907 ; 80$.

13. Dunstan WR. Northern Nigeria: Reports on the results of the mineral survey, (19061907). London House of Parliament, Her / His Majesty's Stationery Office. Series of Colonial Reports. 1908;22.

14. Dunstan WR. Northern Nigeria: Reports on the results of the mineral survey, (19071909). London House of Parliament, Her / His Majesty's Stationery Office. Series of Colonial Reports. 1911;40.

15. Falconer JD. The geology and geography of Northern Nigeria. Macmillan, London. $1911 ; 295$.

16. Russ W. The geology of parts of Niger, Zaria and Sokoto Provinces. Geological Survey of Nigeria Bulletin. 1957;27: 42.
17. Truswell JF. A contribution to the study of older granites in the Nigeria Precambrian with special reference to the Tegina Granites, Unpublished Ph.D. Thesis, University of Cape Town. 1960;178.

18. Ajibade AC. The geology of the country around Zungeru. M.Sc Thesis, University of Ibadan. 1971;123.

19. McCurry P. The geology of the Precambrian to lower Palaeozoic rocks of Northern Nigeria - A review. In: Kogbe, C. A. (Ed.), Geology of Nigeria. Elizabethan Publishers, Lagos. 1976;15-39.

20. Ajibade AC, Fitches WR, Wright JB. The Zungeru mylonites, Nigeria: Recognition of a major unit. Rev de Geology, Geography. 1979;2:359-363.

21. Ajibade AC. Geotectonic evolution of the Zungeru Region, Nigeria. Unpublished Ph.D. Thesis, University of Wales, Aberystwyth. 1980;223.

22. Holt R. Geotectonic evolution of the Anka belt in the Precambrian basement complex of Northwestern Nigeria. Unpublished Ph.D. Thesis, Open University, England. 1982;147.

23. Ogezi AEO. Geochemistry and geochronology of basement rocks from Northwestern Nigeria. Unpublished Ph.D. Thesis, University of Leeds, England. 1977;295.

24. Grant NK. Structural distinction between a met sedimentary cover and an underlying basement in the 600 my old Pan-African domain of North western Nigeria. Geological Society of America Bulletin. 1978;89:50-58.

25. Olade MA, Elueze AA. Petrochemistry of llesa amphibolites and Precambrian crustal evolution in the Pan African domain of Southwestern Nigeria. Precambrian Research. 1979;88:308-312.

26. Elueze AA. Petrography and geochemistry of metasedimentary rocks of the schist belt of Ilesha area, Southwestern Nigeria. Journal of Mining and Geology. 1981;18:57.

27. Elueze AA. Dynamic metamorphism and oxidation of amphibolites of Tegina area, Northwestern Nigeria. Precambrian Research. 1983;14:379-388.

28. Turner DC. Upper proterozoic schist belts in the Nigerian sector of the Pan-African province of West Africa. Precambrian Research. 1983;21:65-79.

29. Durotoye MA, Ige OA. An inventory of talc deposits in Nigeria and their industrial 
application potentials. Journal of Mining and Geolog. 1991;2:27-31.

30. Garba I. The origin and significance of non-aqueous $\mathrm{CO}_{2}$ fluid inclusions in the auriferous veins of Bin Yauri Northwestern Nigeria. Springer Link. 1992;2-9.

31. Danbatta UA, Abubakar YI, Ibrahim AA. Geochemistry of gold deposits in Anka schist belt, Northwestern Nigerian. Journal of Chemical Research. 2009;13:21-34.

32. Amoka IS. Beneficiation of talcose rock from Kagara, North-central Nigeria. Unpublished Master of Technology Thesis, Federal University of Technology, Minna, Nigeria. 2000;211.

33. Garba I. Late Pan-African tectonics and origin of gold mineralization and rare metal Pegmatite in the Kushaka schist belt, Northwestern Nigeria. Journal of Mining and Geology. 2002;1:1-12.

34. Obaje NG. Geology and mineral resources of Nigeria. Springer -Verlag Berlin Heidelberg. 2009;12.

35. Abubakar YI. An integrated technique in delineating structures: A case study of the Kushaka schist belt Northwestern Nigeria. International Journal of Applied Science and Technology. 2012;2:164-173.

36. Ihaza CA, Adekeye JID, Omorinoye OA. Appraisal of the talc bodies of Kagara area, North-western Nigeria and their industrial potentials. Centre Point Journal of Science. 2014;20:151-171.

37. Akintola OA. Petrogenetic study of the talc mineralization in Kagara Area (Sheet 142 SE and part of Sheet 142 SW) Northcentral, Nigeria. M.Sc Thesis, Ahmadu Bello University, Zaria. 2017;147.

38. Truswell JF, Cope RN. The geology of parts of Niger and Zaria provinces, Northern Nigeria. Bulletin of Geological Survey Nigeria. 1963;29:34-48.

39. Yaro SA. Development of a process route for the beneficiation of Mallam Ayuba manganese deposit to ferromanganese feed grade. Unpublished Ph.D. Thesis, Ahmadu Bello University, Zaria. 1998;79.

40. RMRDC. Raw material research and development councils: Solid minerals in Nigeria. Bi-annual Publication. 1999;4:17.

41. NSRMEA. National Steel Raw Materials Exploration Agency, geological report on manganese deposit in Kaoje Bungudu. 2010;3:45-58.

42. Mucke A. The Nigerian manganese -rich iron formation and their host rocks- from sedimentation to metamorphism. Journal of Africa Earth Sciences. 2005;41:407436.

43. Muriana RA, Muzenda E, Abubakre OK. Extraction and production kinetics of industrial - grade manganese sulphate crystal from manganese. Journal of Engineering Research. 2014a;19:78-90.

44. Muriana RA. Discharge evaluation of battery-active chemical manganese dioxide produced from Madaka (Nigeria) manganese ore. Journal of Engineering Research. 2016;20:67-78.

45. Fitches WR, Ajibade AC, Egbuniwe IG, Holt RW, Wright JB. Late Proterozoic schist belts and plutonism in NW Nigeria. Journal of the Geological Society of London. 1985;142:319-337.

46. Udoh AN. Remote sensing interpretation of geology of parts of Kaduna, Kwara and Sokoto States, Nigeria. Unpublished M.Sc. Thesis, Ahmadu Bello University. 1987;122.

47. Ajibade AC, Woakes M, Rahaman MA. Proterozoic crustal development in the Pan-African regime of Nigeria. In: A. Krooner (Editor), Proterozoic crustal evolution. Geodynamic Services American Geophysics Union. 1987;17:259-271.

48. Dada SS. Crust - forming ages and Proterozoic crustal-evolution in Nigeria; of current interpretation. Precambrian Research. 1998;87:65-74.

49. Dada SS, Adojoh O, Rahaman A, Garba I. Lead reservoirs and metallization in Nigeria: Example of a contrasting geological terrain. Journal of Geosciences and Geomatics. 2015;3:28-36.

50. Mucke A, Annor A. Examples and genetic significance of the formation of iron oxides in the Nigerian banded iron -formations. Mineralium Deposita. 1993;28:13614.

51. Mucke A. General and comparative considerations of whole rock and mineral composition of Precambrian ironFormations and their implications. Neues Jahrbuch Mineralogie, Abhandlungen. 2003;179:175-219.

52. Binta $\mathrm{H}$. Upgrading of Wasagu manganese ore to metallurgical grade concentrate. Unpublished M.Sc Thesis, Ahmadu Bello University, Zaria. 2013;66.

53. Binta H, Yaro SA, Thomas DG, Dodo MR. Beneficiation of low grade mangansese ore from Wasagu. Journal of Raw Materials and Development. 2016;10(2): 45-51. 
54. Black R. Precambrian of West Africa. Episodes. 1980;4:3-8.

55. Ajibade AC. Provisional classification and correlation of the schist belts of North Western Nigeria. In: C.A Kogbe (ed) Geology of Nigeria, Elizabeth Publishing Company. 1976;85-90.

56. Wright JB, McCurry P. First occurrence of manganese ores in Northern Nigeria. Economic Geology. 1977;65:103-106.

57. Danbatta UA. A review of the evolution and tectonic setting framework of the schist belts, Northwestern, Nigeria. Journal of Science. 2008;24-35.

58. Dada SS. Crust-forming ages and Proterozoic crustal-evolution in Nigeria. Geoscience Letters. 2008;2:5-11.

59. Bamalli US, Ali M, Mohammed SC. A review of Nigerian metallic minerals for technological development. Natural Resources. 2011;2:87-91.

60. Muriana RA, Muzenda E, Abubakre OK. Carborhermic reduction Kinetic of Kaoje (Nigeria) manganese. Journal of Minerals and Materials Characterization and Engineering. 2014b;2:392-403.

61. McCurry P. The geology of Sheet 21, Zaria. Unpublished M.Sc Thesis, Ahmadu Bello University, Zaria. 1970;134.

62. Bar $\mathrm{P}$, Mucke A. Mineralisation and genesis einiger Nigerian ischer manganv rkornrncn (Tudun Kudu Hill,Ungwan Malam Ayuba, bei Gangara, Ruwan Doruwa and Maraba Hill). Fortschr. 1982;1:148-149.

63. Moneme PC, Scott PW. The mineralogy of Malam Ayuba manganese mineralization in Maska, Sheet (101). Nigerian Mining
Geosciences Society $19^{\text {th }}$ Annual Conference, Warri. 1983;23-24.

64. Moneme PC, Scott PW, Dunham AC. Occurrence of manganese ores in Zaria Area, Kaduna State. Nigerian Mining Geosciences Society Abstracts, $18^{\text {th }}$ Annual Conference, Kaduna. 1982;1718.

65. Mucke A, Okujeni C. Geological and ore microscopic evidence on the epigenetic origin of the manganese occurrences in Northern Nigeria. Journal of Africa Earth Sciences. 1984;3:209-225.

66. Raeburn C. Tinstone in Calabar. Bulletin of Geological Survey of Nigeria. 1927;11:7288.

67. Bafor BE, Mucke A. The genesis of manganese concretions in the Igarra area, Southwestern Nigeria. Journal of African Earth Sciences. 1990;10:595-601.

68. Vandi DK. Geology and geochemistry of manganese ores in Mujara, Mubi South, Northeast Nigeria. B.Sc Thesis Modibbo Adamawa University of Technology, Yola. 2014;32.

69. Bartholomew A. The geology and geochemical secondary dispersion pattern of manganese occurrence in Ugoge via Giwa, Kaduna State, Nigeria. Unpublished B.Sc Thesis, Ahmadu Bello University, Zaria, Nigeria. 1982;61.

70. Widadason GA. The geology and geochemical secondary dispersion pattern of the manganese occurrence at Ugoge (Tudun Kudu) Southeastern Sector, Department of Geology, Ahmadu Bello University, Zaria, Nigeria (Unpublished). 1982;67.

(C) 2019 Akintola; This is an Open Access article distributed under the terms of the Creative Commons Attribution License (http://creativecommons.org/licenses/by/4.0), which permits unrestricted use, distribution, and reproduction in any medium, provided the original work is properly cited.

Peer-review history:

The peer review history for this paper can be accessed here: http://www.sdiarticle3.com/review-history/46745 